\title{
The U.S. Geological Survey Sea-Going Women
}

BY DAWN LAVOIE AND DEBORAH HUTCHINSON

In this, the dawn of the $21^{\text {st }}$ century, women are an established part of the scientific, technical, and management workforce in the U.S. Geological Survey (USGS). This may seem a mundane fact not worth thinking about, but it is the premise of this article that we cannot understand where we are without looking back at the path we've traveled, and that path is worth thinking about. When we do this, we see that the social changes that have shaped our world during the 125 years of USGS existence are also reflected in the history of women in the USGS. The prominence of women in the USGS is a relatively recent development and to put that in context, we shall briefly review the history of the marine activities within the USGS, the changing roles of the USGS, and at the appropriate points, populate the story with those women who blazed the trail to the point where we find ourselves today.

In 2004, the USGS celebrated its $125^{\text {th }}$ anniversary. For the first eight decades of its history, the USGS did not have a separate mandate to study the marine environment; therefore, the USGS did not begin hiring oceanographers until the marine program began in the early 1960s. Even now, many of the women conducting marine research at the USGS are classified as geophysicists, geologists, chemists, micropaleontologists, engineers, and physical scientists. The absence of a written history of marine activities within the USGS means that much of this account is drawn from anecdotes and memories.

\section{EARLY DAYS}

In 1879, President Rutherford B. Hayes signed the bill appropriating money for the various expenses of the federal government for the fiscal year. The bill included a brief section establishing a new agency, the U.S. Geological Survey, placing it within the Department of the Interior, and charging it with the responsibility for "classification of the public lands, and examination of the geological structure, mineral resources, and products of the national domain" (Rabbitt, 1989). The first mandate, the classification of public lands, was initiated by the first 38 USGS employees_-all men.
One of the first women geologists hired by the USGS, Julia Gardner, earned her Ph.D in paleontology at Johns Hopkins University in 1911. Shortly thereafter, she joined the Military Geologic Unit of the USGS where she helped locate Japanese beaches from which incendiary bombs were being launched by identifying shell species in the sand ballast of the balloons (http://www.cartage.org.lb/en/ themes/Biographies/MainBiographies/ G/Gardner/1.html).

Seventy-five years later, in 1954, the USGS had 7,000 employees and a greatly expanded commitment to basic research and the advancement of geology for public service. The USGS had played a significant role in mapping, exploring, and classifying federal lands, particularly in the western frontier, as well as iden-

Dawn Lavoie (dlavoie@usgs.gov) is Associate Program Coordinator, Coastal and Marine Program, U.S. Geological Survey, Reston, VA, USA. Deborah Hutchinson is Research Geologist, U.S. Geological Survey, Woods Hole Science Center, Woods Hole, MA, USA. 
tifying raw materials that had helped build the manufacturing economy that propelled the United States into a global economic and military power (Rabbitt, 1989). During the 1950s, the USGS focused on the nation's requirements to meet increasing demands for raw materials. Two events in the 1950s laid the foundation for the marine program: (1) the USGS acquired the responsibility for oil- and gas-lease operations on the Outer Continental Shelf (Rabbitt, 1989), and (2) the nations of the world came together to develop an international treaty on jurisdiction of the world's oceans and seafloor, the 1958 United Nations Convention on the Law of the Sea.

The USGS marine program was established in 1962 with locations at the USGS center in Menlo Park, California, and a field office collocated with the Woods Hole Oceanographic Institution in Woods Hole, Massachusetts. The mission these early years, women were mostly in non-scientific support roles as secretaries and/or administrative staff.

Three events over the next two decades changed the direction of the fledgling marine program: (1) the great oil spill in the Santa Barbara Channel off California in 1969, which threatened marine life and fouled local beaches and prompted increased environmental action (Tyler, 2004), (2) the growing acceptance of the plate tectonic "revolution" as a paradigm of Earth processes in the early 1970s, which excited a new generation of marine geologists to explore the oceans and its seafloor, and (3) the Arab Oil Embargo in 1973, which made the nation realize the vulnerability of its energy supplies. As a result, major increases in funding were approved for the USGS marine program to work on environmental and energy-related issues on continental shelves around the United

\section{From here on, it appears that the number and roles}

of women scientists across the USGS in general and within the marine sciences in particular will be a function of the supply of women in oceanography and related marine sciences rather than prejudgments of their ability and "place."

for the marine program was to map and evaluate the composition, structure, and mineral resources of the ocean floor and study the geologic and hydrologic processes that operate within the oceans to better understand the conditions under which ancient sediments and ore deposits were formed (Rabbitt, 1989). During
States. During the same time period, the women's liberation movement in the 1960s paved the way for women to move into careers like geology and oceanography, which were previously considered male domains.

With the increased funding came major field programs and the need for staff to participate in the sometimes labor-intensive field work. The early to mid-1970s witnessed the hiring of many women, either students or bachelor's degree recipients, in science support and sea-going roles. Some of these women who first stood watch in the mid-1970s are still with, or spent much of their adult careers at, the USGS in science or management roles (Figure 1) (Helen Gibbons, Christine Gutmacher, Debbie Hutchinson, Kaye Kinoshita, Barbara Lidz, Jill McCarthy, Pat McCrory, Ann McKinney (aka Swift), Diane Miniasian, Paula Quinterno, Carol Reiss, Kathy Scanlon, and Florence Wong). Many others served the USGS, then returned to graduate school and research careers outside USGS (Robin Bell, Kathy Cashman, Margaret Goud, Nancy Hardin, Kathy Kent, Audrey Meyer, Stephanie Pfirman, and Pat Wiberg) or teaching (Ann Slate Martin and Sally Wood Needell). Interestingly, the need for sea-going personnel often included secretarial staff to help write reports at sea (e.g., East Coast AMCOR drilling cruise in 1976); some of these women gained experience and opportunities to move from secretarial into technical positions (e.g., Nancy Soderberg, now Data Librarian/Archivist for the Woods Hole Office and Elizabeth Winget, now retired, who served as a scientific editor for many years).

Opportunities for women in positions of leadership at sea were slow to develop. Women, however, were responsible for important duties at sea, for example, navigation watch, data watch, data curation, engineer, and engineering technician. The earliest record of a USGS woman as sea-going chief scientist was probably Debbie Hutchinson in 1975 
aboard a contract vessel, the Argue Martin, conducting seismic profiling in Lake Ontario. Two years earlier, Gretchen Luepke served as chief scientist for a beach sampling program in southern Oregon, but this did not involve ship operations.

The first woman scientist with a Ph.D. hired into the Marine Program was Dr. Bonnie McGregor, who joined the Atlantic-Gulf of Mexico Branch at the small field office on Fisher's Island, Miami, Florida in 1979. Marlene Noble and Debbie Hutchinson completed their doctoral degrees at the University of Rhode Island in 1983 and 1984, respectively, while working at the USGS. Jan Morton and Jill McCarthy joined the marine program in Menlo Park with their newly awarded Ph.D.s in the following two years. By the mid-1980s, the USGS had a small, but geographically distributed and growing number of women scientists in positions of oceanographic leadership. Their research covered a wide range of topics (circulation of the coastal ocean, seafloor processes, deep geophysics, and tectonics), and was consistent with the mission of exploring the environment, resources, and hazards of the U.S. continental margins.

With the excitement generated by the theory of plate tectonics, blue-water exploration became a new and exciting focus of USGS activity. Women at the Woods Hole field office were inspired by early pioneering women oceanographers. Two in particular, Mary Sears and Betty Bunce (Figure 2) became role models for USGS women oceanographers. Mary Sears (1905-1997) was closely involved in the development of the Woods Hole Oceanographic Institution. Although not a sea-going oceanographer (since

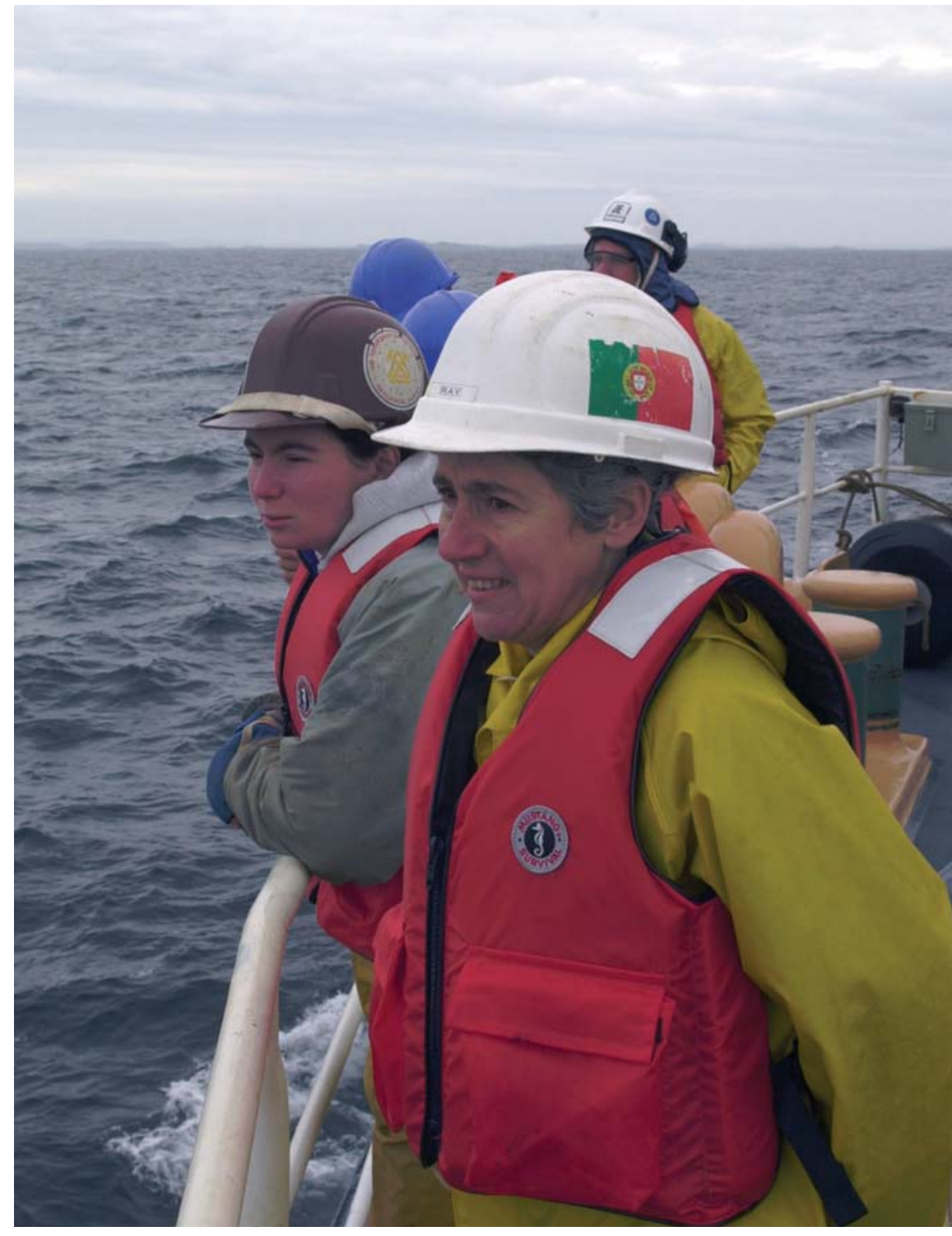

Figure 1. Debbie Hutchinson (Woods Hole Science Center, right) and Marinna Martini (Woods Hole Science Center, left) in May, 2001 Massachusetts Bay during a tripod turn-around cruise aboard the Coast Guard Cutter Marcus Hanna. Photograph by Dann Blackwood.

women were not permitted to go to sea until many years later), Mary Sears, first Oceanographer of the Navy, made her mark in marine science by editing the journals and books in which oceanographers published their results and by helping to establish the journals DeepSea Research and Progress in Oceanogra- phy (http://www.whoi.edu/media/news_ usns.sears_release.html).

Betty Bunce (1915-2003) was the first woman scientist to go to sea routinely. She opened the door for many other women pursuing careers in oceanography; she was the first American woman to serve as chief scientist on a major 


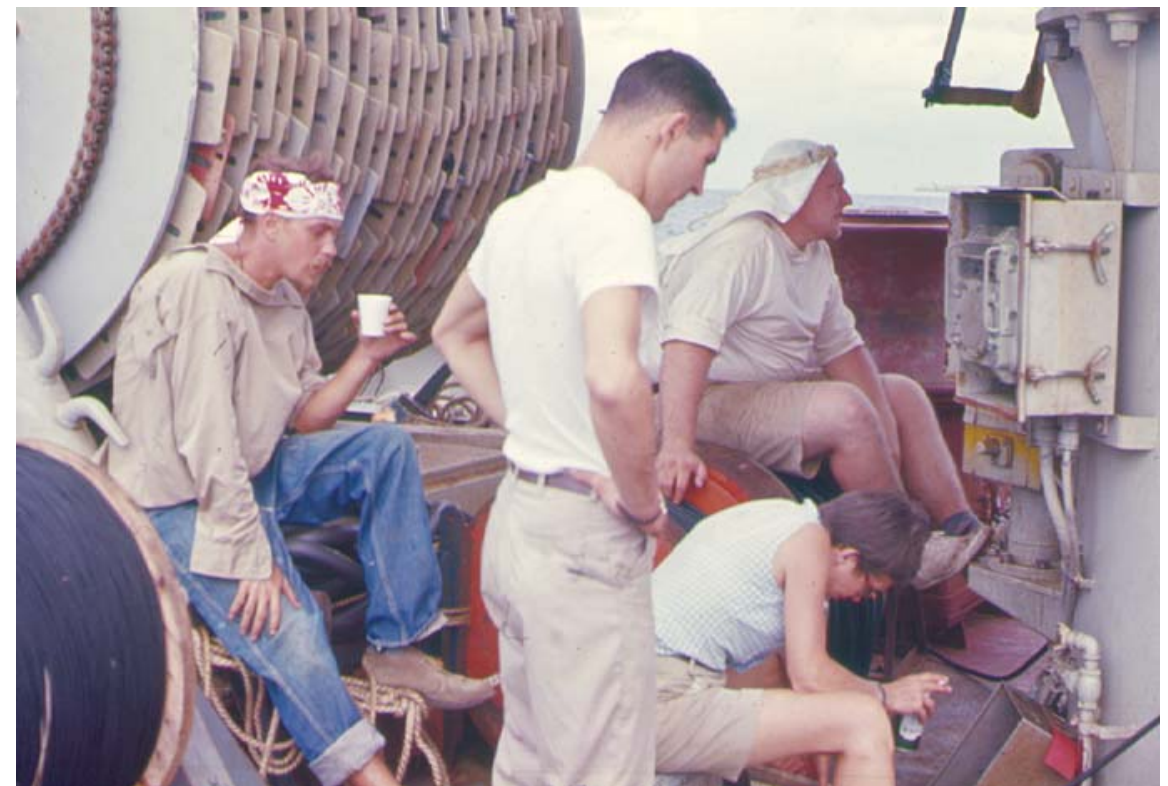

Figure 2. Betty Bunce (1915-2003) showing the realities of being chief scientist during the loss of equipment, in this case a dredge. The tensiometer holding the dredge has just registered only the weight of the wire, and the last dredge is lost. With Betty on this 1964 International Indian Ocean Expedition cruise on the R/V Chain are F. Campbell (left), an unnamed ship's electrician (center) and F. Hess (right). Photograph by Tom Aldrich.

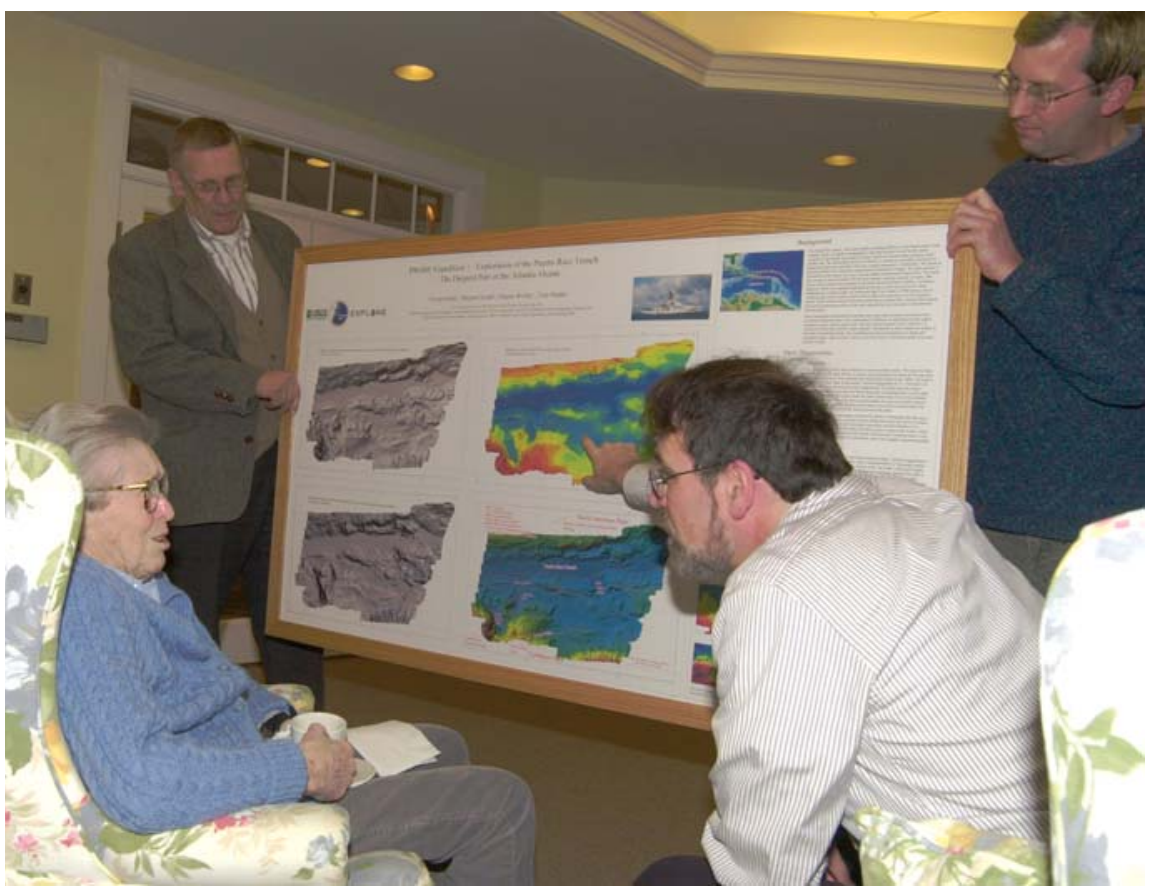

Figure 3. Betty Bunce being presented with a poster with maps and images of the fault bearing her name. Clockwise from left: Betty Bunce, Hartley Hoskins, Dave Du Bois, and Uri ten Brink. Photograph by Dann Blackwood. oceanographic expedition and she subsequently served as chief scientist on many cruises, including a major portion of the National Science Foundation-sponsored International Indian Ocean Expedition (IIOE) in 1964 (Figure 2). She was the first woman to dive in Alvin (1965). In 1971, she headed a team on the Chain conducting site surveys in the Indian Ocean for future scientific drilling. She was then chosen as the first woman to be a chief scientist in the Deep Sea Drilling Project aboard Glomar Challenger. Significantly, for the scientists in the USGS who continue her work, Betty conducted some of the early systematic studies of the Puerto Rico Trench, the deepest part of the Atlantic Ocean. Recent exploration of the trench, partially funded by the National Oceanic and Atmospheric Administration (NOAA) Office of Ocean Exploration, was conducted by a team from the USGS and the University of New Hampshire. This joint effort has produced for the first time a high-resolution map of part of the floor of the Puerto Rico Trench. One of the major discoveries from this mapping effort is a large active tectonic fault system at the bottom of the trench, now named the Bunce Fault, in honor of Dr. Betty Bunce (Figure 3).

President Richard Nixon addressed the energy crisis resulting from the oil embargo in 1973 by approving the Alaska pipeline and expanding energy research and development efforts designed to make the United States self-sufficient by 1980 . In particular, the prospect that oil wells would be drilled along U.S. continental margins initiated a cooperative program between the USGS and the $\mathrm{Bu}$ reau of Land Management to determine the fate of sediments and pollutants as- 


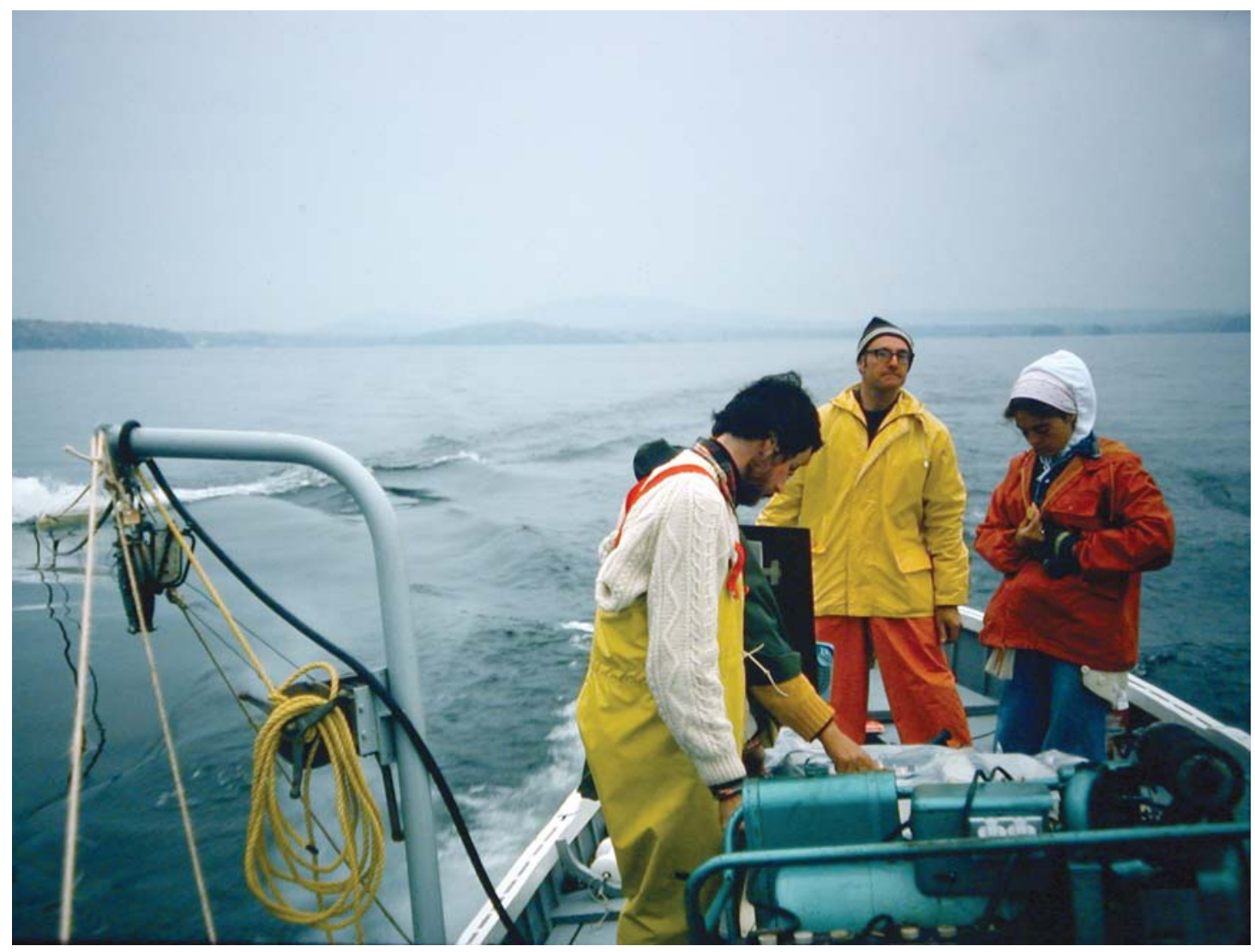

Figure 4. USCS cruise aboard the R/V Bruno Schmidt in 1974 in Lake Champlain. Patty Forrestel (shown) and Debbie Hutchinson (who took the picture) served as watch standers and navigators for the Uniboom ${ }^{\oplus}$ profiling survey. Dave Folger (steering the boat) was chief scientist, and D. Edwards (left) was electronics technician.

sociated with oil drilling in the coastal ocean. This sediment and pollutant transport program expanded into major program thrusts that still continue. The great national investment in marine knowledge and increased resources within the USGS marine program required an expanded scientific workforce and talented young women began entering the marine sciences and were soon routinely going to sea in boats large and small (Figure 4).

The 1980s brought major change to the USGS. In 1982, Secretary of Inte- rior James Watt reorganized parts of the USGS to form a new bureau, the Minerals Management Service, charged with the responsibility to manage offshore federal leasing. Shortly thereafter, in 1983, the remaining USGS marine group faced a huge challenge when President Ronald Reagan proclaimed an Exclusive Economic Zone (EEZ) extending 200 nautical miles beyond the shoreline (Rabbitt, 1989). This act more than doubled the area of the national domain to be mapped and assessed for mineral and energy resources (Rabbitt, 1989).
The USGS accepted the challenge to systematically map this new frontier and in 1984, the USGS launched a 10-year program using a state-of the-art, long-range side-scan sonar system (GLORIA) to image the deep-water portions of the newly established EEZ. This program, called EEZ-SCAN was carried out cooperatively with the Institute of Ocean Sciences in Great Britain and resulted in a significant increase in funding for the Marine Program. This systematic mapping effort also resulted in USGS and NOAA establishing a joint office, the Office for 


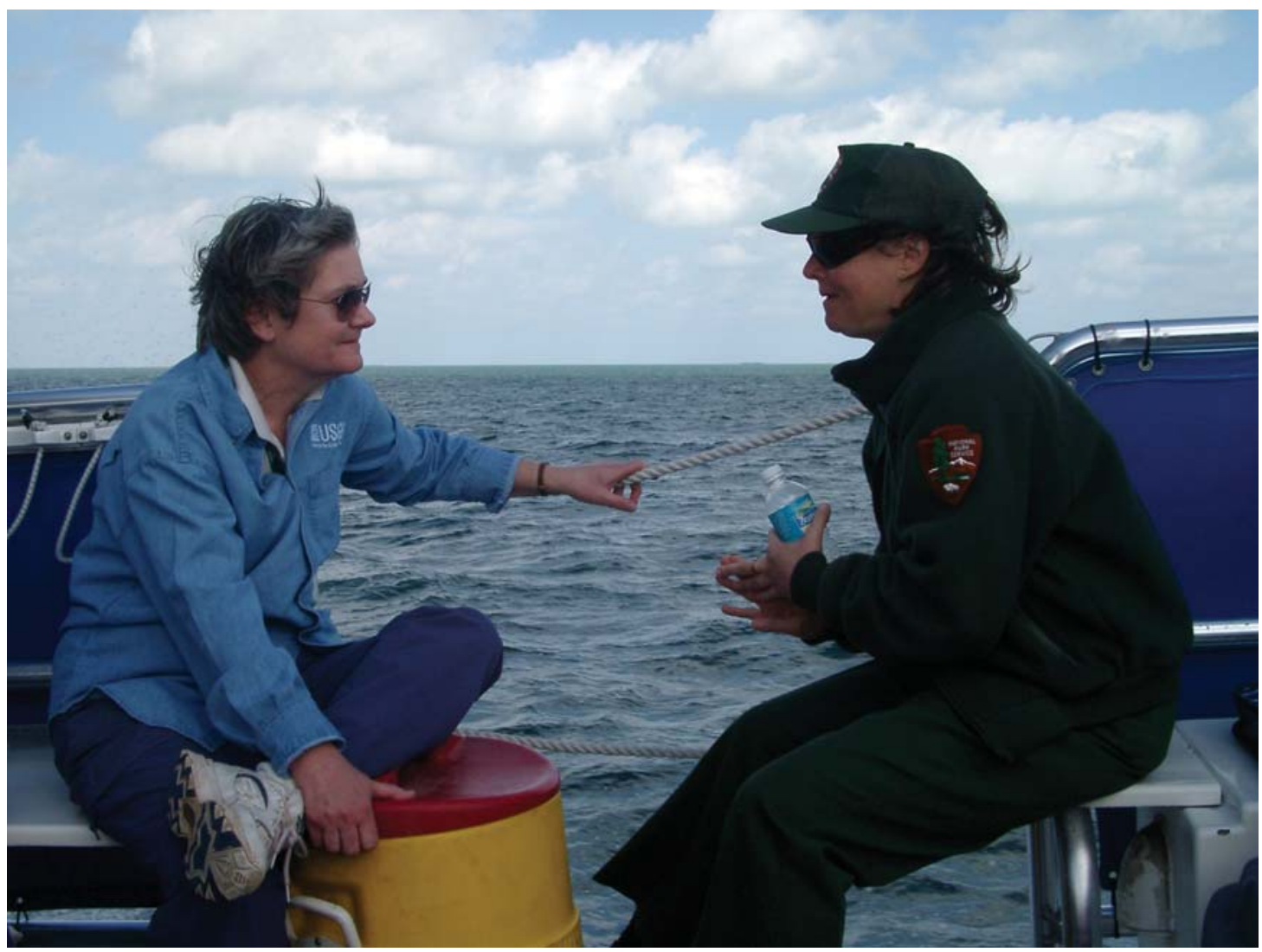

Figure 5. Bonnie McGregor (left) conferring with Linda Canzanelli (right) of the National Park Service in Biscayne National Park. Dr. McGregor retired as Regional Director, Eastern Region, U.S. Geological Survey, in 2004. She was instrumental in the success of the EEZ-SCAN GLORIA mapping program during much of the 1980s and early 1990 s.

Mapping and Research in the EEZ, to coordinate interagency activities and share information on discoveries, such as channels meandering across the seafloor for over $100 \mathrm{~km}$, and massive underwater landslide debris fields with blocks over $1 \mathrm{~km}$ high. This was an exciting time for oceanographers and marine geologists to document and understand the dynamic environment of the seafloor. During this period, Bonnie McGregor (Figure 5) served as lead scientist and program coordinator for the EEZ-SCAN program, and then as Associate Chief for Marine Programs in the Office of Energy and
Marine Geology. The intensive effort to map the EEZ focused the USGS marine activities and resources into the 1990s.

In the early to mid 1990s, the cadre of women marine scientists began to change as they assumed technical leadership and management responsibilities in the USGS. In 1992, Bonnie McGregor was the first woman in the USGS to achieve a Senior Executive Service position, as the Assistant Chief Geologist for Programs. Subsequently she became the Associate Director for Science followed by the Regional Director, Eastern Region, from which she retired in 2004.
Debbie Hutchinson became the Center Director for the Coastal and Marine Team in Woods Hole for six years, during which she oversaw expansion of USGS coastal programs and had less time for scientific research. She has since returned to research leading the USGS marine methane hydrates research and is still going to sea. Hutchinson has served as mentor for a new generation of marine scientists coming up from behind, including Jane Denny, Fran Lightsom, Erica Hammer-Klose, Ellen Mecray, and Marinna Martini (Figure 6). Jan Morton, after serving as the coordinator of USGS 


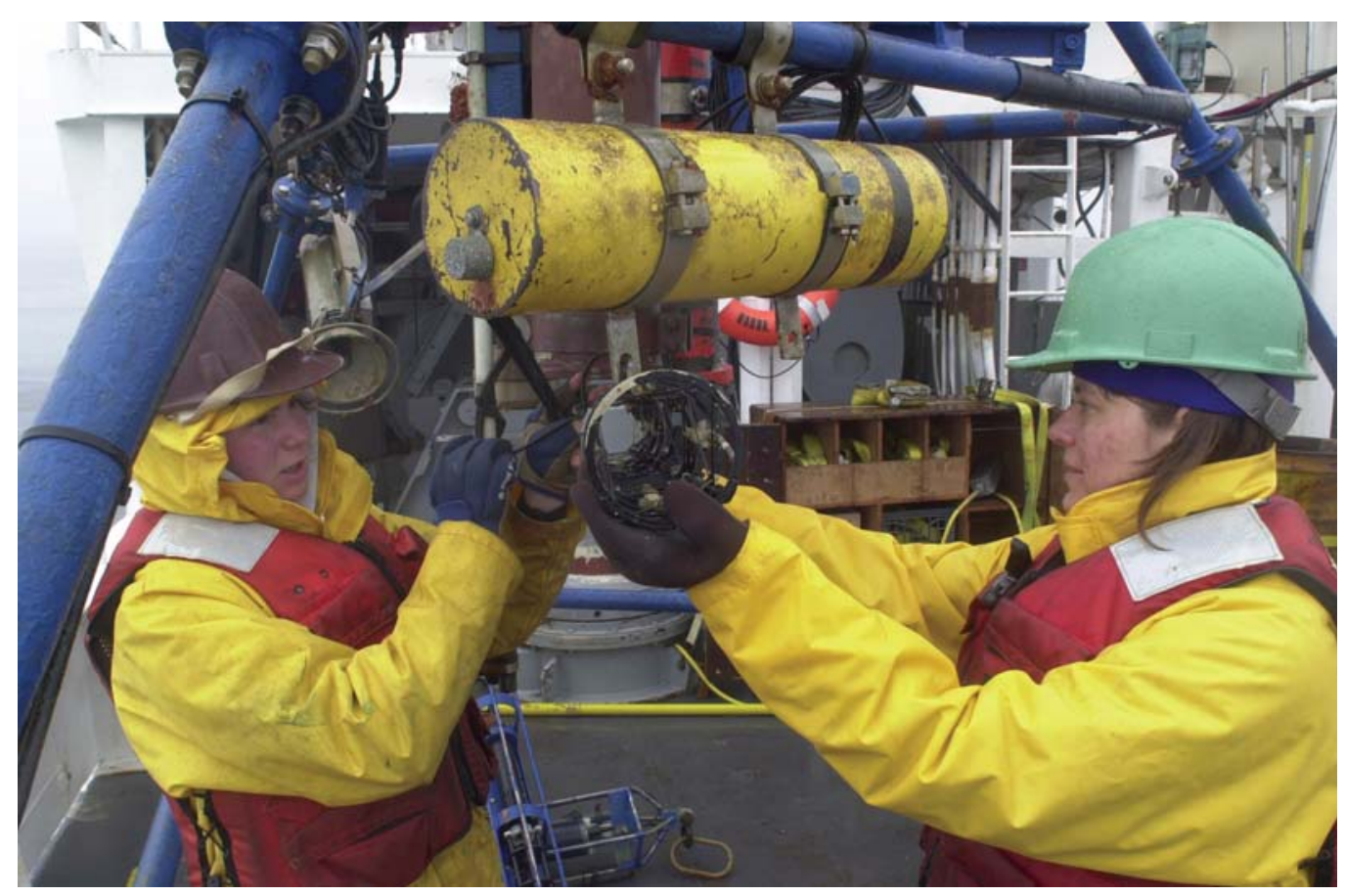

Figure 6. Above: Marinna Martini (left, Woods Hole Science Center) and Joanne Ferreira (right, Menlo Park Science Center) securing a BASS sensor from a tripod recovered aboard R/V Endeavor in the New York bight, to prevent it from becoming damaged in anticipation of heavy seas. Photograph by Dann Blackwood. Right: Ellen Mecray taking a subsample from the SEABOSS grab sampling video system in 1999 in Long Island Sound aboard the R/V Connecticut. Photograph by Dann Blackwood.

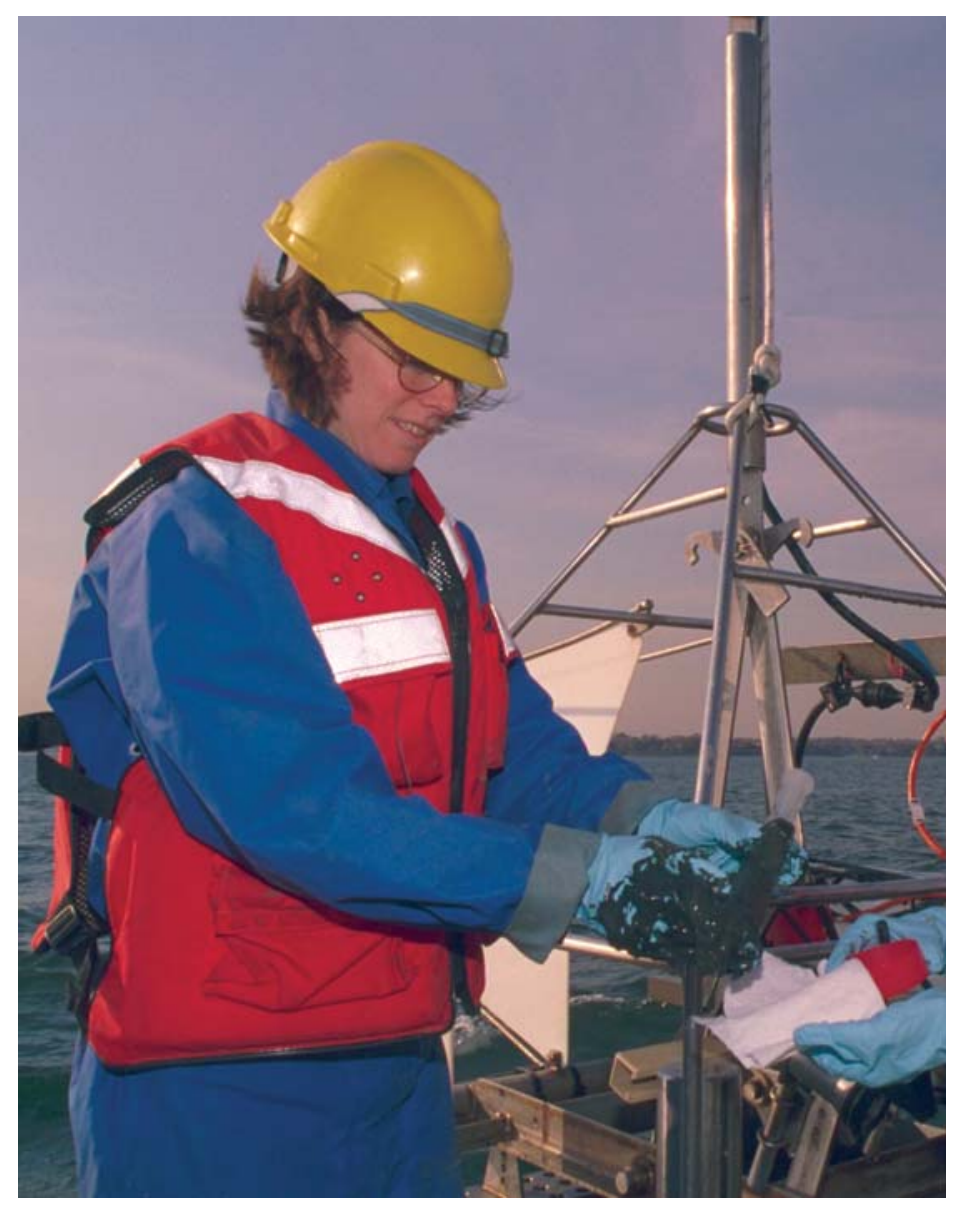


marine programs, became deeply involved in setting up a management and science-planning database for the USGS using computer skills learned as a geophysicist. Frances Lightsom now heads up the Knowledge Bank development effort, a substantial effort to store and serve all the Coastal and Marine Geology Program data. Some women retired while others stayed in oceanography responding to changing socioeconomic, scientific, and environmental issues.

Marlene Noble, still active in oceanography, develops and leads programs, now primarily on the west coast, that determine how sediments and suspended pollutants move through the coastal ocean. New women have joined the USGS in administrative science leadership roles (e.g., Lisa Robbins from academia, now Team Chief Scientist in the St. Petersburg office; Dawn Lavoie from the Naval Research Laboratory, now Associate Program Coordinator for the Coastal and Marine Geology Program in the Headquarters office, Reston, Virginia).

\section{TODAY}

In the new millennium, the heyday of blue-water seafloor exploration has ended in spite of the fact that we know less about what lies under the ocean surface than we do about the surface of Mars. The number of USGS sea-going women ranges between 20 and 30 percent of the professional (i.e., research and technical) staff, although the number of women who are research scientists who lead cruises is still disappointingly low (less than 5 to 10 percent of all research scientists). This is partially offset by the much higher percentage of women who are scientific managers at the USGS (from
20 to 60 percent, depending on the level of management). Expensive deep-water exploration has decreased within the USGS and is only being done with coordination across the federal ocean science agencies. Research within the Coastal and Marine Geology Program increasingly responds to coastal rather than blue-water issues, with a focus on applied local and regional activities done in conjunction with partners and collaborators. The USGS mission in the marine environment is to contribute science understanding required for clean coastal waters, healthy ecosystems, sustainable environments and resources, safe communities, and reliable marine transport.

Where will we go in the future and what will be the role of women? Recommendations of the U.S. Commission on Ocean Policy (a commission appointed by the President) and the President's written response may once again change the emphasis of the USGS marine and coastal program. The report emphasizes ecosystem-based management for ocean and coastal resources. The need to measurably improve polluted runoff in impaired watersheds from both point and non-point sources, control the spread of invasive species, work toward "no net loss" of our wetlands, effectively manage our sand and gravel resources, address atmospheric deposition of pollutants, and undertake studies to legally define the continental shelf under provisions of the United Nations Convention on the Law of the Sea are issues that are currently engaging USGS scientists across marine and other programs (Groat, 2004). Seafloor mapping and characterization needed to understand the location and character of seafloor habitats, the scope of changes brought on by natural variability and human disturbance, and the capacity for stressed habitats to recover require the geologic expertise provided by the USGS and will demand our energy for the next decade.

In this endeavor, we believe basic and applied research activities will be undertaken by men and women within the USGS without regard to gender. One look at the USGS management structure supports this assumption. In the science leadership positions within the USGS, three of five Associate Directors are women; one of three Regional Directors is a woman, and six of thirty science program coordinators in the USGS are women. Heads of major functional areas within the USGS (e.g., Budget Office, Public Affairs Office, Administrative Policy and Services, and Geographic Information Office) are women. In short, the pioneering era for women in the USGS has paved the way for these leadership roles. From here on, it appears that the number and roles of women scientists across the USGS in general and within the marine sciences in particular will be a function of the supply of women in oceanography and related marine sciences rather than prejudgments of their ability and "place." Thank you, Pioneers. ש্]

\section{REFERENCES}

Groat, C. 2004. Coastal and Marine Hazards: People, Infrastructure and Ecosystems at Risk. Sea Technology 45:19-21.

Rabbitt, M. 1989. The United States Geological USGS: 1879-1989. USGS Circular 1050. U.S. Geological Survey, Washington, D.C., 52 p.

Tyler, H. 2004. Big Oil and the California Coast: Leading up to the Great 1969 Santa Barbara Oil Spill, The Environmental Analysis Letter II(2). Pomona College, Program in Environmental Analysis, News, Reviews, and Commentary. [Online] Available at: http://ea.pomona.edu/ oct03.html. 